Canadian Journal of Applied Linguistics

Revue canadienne de linguistique appliquée

\title{
Self-Efficacy Beliefs of Novice French as a Second Language Teachers: A Case Study of Ontario Teachers
}

\section{Shelley Cooke et Farahnaz Faez}

Volume 21, numéro 2, 2018

URI : https://id.erudit.org/iderudit/1057963ar

DOI : https://doi.org/10.7202/1057963ar

Aller au sommaire du numéro

\section{Éditeur(s)}

University of New Brunswick

\section{ISSN}

1920-1818 (numérique)

Découvrir la revue

Citer cet article

Cooke, S. \& Faez, F. (2018). Self-Efficacy Beliefs of Novice French as a Second Language Teachers: A Case Study of Ontario Teachers. Canadian Journal of Applied Linguistics / Revue canadienne de linguistique appliquée, 21(2), 1-18. https://doi.org/10.7202/1057963ar

\section{Résumé de l'article}

Cette étude a examiné les perceptions d'efficacité personnelle d'enseignants du français langue seconde (FLS) novices à l'élémentaire. Afin d'examiner les évaluations d'efficacité personnelle d'enseignants du français-cadre $(n=14)$ et d'immersion française $(n=13)$ quant à leur enseignement des programmes de FLS, une approche de méthodes mixtes a été adoptée. Un questionnaire, explorant les perceptions personnelles d'efficacité selon quatre catégories : méthodologie générale d'enseignement, didactique de la langue seconde, compétence langagière et savoir culturel, a été administré. Les résultats ont révélé que les deux groupes de participants ne se percevaient pas comme étant particulièrement confiants quant à leur enseignement à la fin de leur programme de formation d'enseignants. Les perceptions de confiance des deux groupes ont augmenté envers leurs habiletés d'enseignement du FLS avec l'expérience en salle de classe. Néanmoins, les enseignants d'immersion française rapportaient un sentiment de confiance plus élevé que leurs collègues en français-cadre dans les quatre catégories. Les implications des résultats pour les programmes du français-cadre et de l'immersion française, ainsi que pour les programmes de formation d'enseignants du FLS seront traitées.
Copyright (c) Shelley Cooke, Farahnaz Faez, 2018

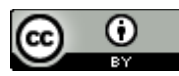

Ce document est protégé par la loi sur le droit d'auteur. L'utilisation des services d’Érudit (y compris la reproduction) est assujettie à sa politique d'utilisation que vous pouvez consulter en ligne.

https://apropos.erudit.org/fr/usagers/politique-dutilisation/ 


\title{
Self-Efficacy Beliefs of Novice French as a Second Language Teachers: A Case Study of Ontario Teachers
}

\author{
Shelley Cooke \\ Western University \\ Farahnaz Faez \\ Western University
}

\begin{abstract}
The purpose of this study was to examine the self-efficacy beliefs of novice elementary French as a second language (FSL) teachers. A mixed methods approach was used to investigate self-efficacy appraisals of core French $(n=14)$ and French immersion $(n=13)$ teachers in delivering instruction in FSL programs. A questionnaire was administered that explored teachers' self-perceived efficacy in four categories: general teaching methodology, second language pedagogy, language proficiency, and cultural knowledge. Findings revealed that both groups of participants did not perceive themselves to be particularly confident in delivering instruction upon completion of their teacher education programs. The selfperceived confidence in FSL teaching abilities of both groups increased with classroom experience. However, French immersion teachers reported a higher sense of efficacy than their core French colleagues in all four categories. Implications of the findings for core French and French immersion programs as well as FSL teacher preparation programs are discussed.
\end{abstract}

\section{Résumé}

Cette étude a examiné les perceptions d'efficacité personnelle d'enseignants du français langue seconde (FLS) novices à l'élémentaire. Afin d'examiner les évaluations d'efficacité personnelle d'enseignants du français-cadre $(n=14)$ et d'immersion française $(n=13)$ quant à leur enseignement des programmes de FLS, une approche de méthodes mixtes a été adoptée. Un questionnaire, explorant les perceptions personnelles d'efficacité selon quatre catégories : méthodologie générale d'enseignement, didactique de la langue seconde, compétence langagière et savoir culturel, a été administré. Les résultats ont révélé que les deux groupes de participants ne se percevaient pas comme étant particulièrement confiants quant à leur enseignement à la fin de leur programme de formation d'enseignants. Les perceptions de confiance des deux groupes ont augmenté envers leurs habiletés d'enseignement du FLS avec l'expérience en salle de classe. Néanmoins, les enseignants d'immersion française rapportaient un sentiment de confiance plus élevé que leurs collègues en français-cadre dans les quatre catégories. Les implications des résultats pour les programmes du français-cadre et de l'immersion française, ainsi que pour les programmes de formation d'enseignants du FLS seront traitées. 


\section{Self-Efficacy Beliefs of Novice French as a Second Language Teachers: A Case Study of Ontario Teachers}

\section{Introduction}

In order to be successful in the classroom, teachers require more than just knowledge of content and pedagogy (Knoblauch \& Woolfolk Hoy, 2008). A strong sense of efficacy - "one's belief in his or her capability to organize and execute courses of action required to successfully accomplish a specific teaching task in a particular context" (Tschannen-Moran, Woolfolk Hoy, \& Hoy, 1998, p. 233) - appears to be one of the most important qualities of effective teachers (Henson, 2001). Teachers' beliefs regarding their capabilities in the classroom have been shown to have a notable impact on the entire educational process. These views influence teachers' instructional practices (Gibson \& Dembo, 1984); their classroom behaviour (Tschannen-Moran et al., 1998); and the classroom environment they create (Bandura, 1997). Teacher efficacy is also linked to students' achievement (Ross, 1998; Swanson, 2014) and motivation (Tschannen-Moran et al., 1998). Swanson (2010) reported that teacher efficacy is further linked to teachers' decisions to remain in or leave the profession, a significant finding given the shortage of French as a second language (FSL) teachers in Canada, the context of this study. Equally important is the fact that the highest attrition rate is among language teachers in their first 5 years on the job (Swanson, 2010, 2012, 2014).

Officially, Canada is a bilingual country but a relatively small percentage of its residents are proficient in both English and French, and levels of French language proficiency, in particular, are not satisfactory (Statistics Canada, 2011). The number of people who reported being able to conduct a conversation in both languages in 2011 was only $17.5 \%$ of the population (Statistics Canada, 2011). The Government of Canada has launched a number of initiatives outlining a commitment to improve second language (L2) programs in schools and to provide provinces and territories with financial support to recruit L2 specialists and increase the number of qualified teachers (Government of Canada, 2003, 2008, 2013). The Roadmap for Canada's Official Languages 2013-2018 reaffirmed a renewed commitment to strengthen Canada's official languages across the country. However, in 2014, a report based on a 2013 study of French L2 programs in Canada showed that there continued to be a shortage of teachers who specialized in teaching FSL, despite the government's efforts (Standing Committee on Official Languages, 2014). Salvatori (2009) reported that the shortage of FSL teachers affects the quality of education and sometimes results in hiring teachers who do not have adequate language skills or do not know how to teach an L2. In light of the changing landscape, it is important to understand FSL teachers' perceptions of their confidence in their ability to deliver instruction in their classrooms.

\section{Core French and French Immersion Programs in Canada}

In Canada, education is the responsibility of individual provinces and territories, and FSL programs vary across these jurisdictions. In Ontario, the context of this study, FSL is generally offered through three programs: core French $(\mathrm{CF})$, a mandatory program in which most students are taught French as a subject for one period a day (i.e., 20-40 minutes) starting in Grade 4; French immersion (FI), an optional early immersion program 
in which French is not only taught as a subject, but also serves as the language of instruction in other subjects (i.e., math, science); and Extended French (EF), an optional late immersion program in which French is the language of instruction for one or two foundation subjects in addition to French as a subject.

Throughout the past two decades, an important educational goal for the Government of Canada was to double the number of Canadian secondary school graduates with a functional level of bilingualism in their second official language by the year 2013 (Government of Canada, 2003). Meeting the federal government's goal has proved challenging given that the study of French in schools, particularly within the CF program, is often marginalized (Lapkin, Mady, \& Arnott, 2009). Teachers of CF often feel that their subject is not taken seriously and is viewed as less important than other subjects, not only by principals, colleagues, and parents, but also by students (E. Richards, 2002). Anecdotal evidence suggests that these attitudes often contribute to negative behaviour on the part of CF students and a blatant disregard for not only the subject itself, but also the teacher. Mollica, Philips, and Smith (2005) reported that many CF teachers believe they are viewed merely as preparation time for other teachers in the school, and they feel isolated and unimportant. Additionally, and perhaps even more significant, is the fact that many of these teachers do not have dedicated FSL classrooms (Lapkin, MacFarlane, \& Vandergrift, 2006; Mollica, et al., 2005, E. Richards, 2002), which forces them to rely on carts to transport their materials from room to room. Mollica et al. (2005) maintained that the absence of a classroom is a striking indication of the position the CF program holds within school boards and in the estimation of administrators. In a Canada-wide survey of the challenges facing FSL teachers, Lapkin et al. (2006) reported that the majority of participants deemed commercial resources to be poor or adequate and that more than $40 \%$ claimed that they did not have a classroom.

\section{Novice Teachers}

The early years of teaching are a critical time for teachers. Woolfolk Hoy (2000) reported that although teachers' sense of efficacy increased during preservice teacher education, it decreased with experience as a teacher. Teachers form their efficacy beliefs in their early years (Bandura, 1997) and either enhance these beliefs during this time or leave the profession (Tschannen-Moran \& Woolfolk Hoy, 2001). Unlike most professions, novice teachers have as much responsibility as their more experienced colleagues (Fantilli $\&$ McDougall, 2009; Tait, 2008) and given their inexperience, they face many new challenges. Studies targeting the challenges encountered by beginning teachers (e.g., Fantilli \& McDougall, 2009; McIntyre, 2003) have reported that new teachers expressed a desire for teacher education programs to better prepare them for what was required in their roles.

In 2003, as part of a Transition to Teaching study conducted by the Ontario College of Teachers, new teachers expressed unhappiness with their teaching assignments, reporting often getting the most difficult assignments or those for which they did not have the necessary training or resources (McIntyre, 2003). Beginning teachers identified mentoring as a priority, and expressed the need for help, advice, and time from experienced teachers. Fantilli and McDougall (2009) found that new teachers in Ontario faced numerous challenges, including lack of access to classroom resources, classroom management, and difficulties in planning. Additionally, participants in the study often felt anxious due to the 
absence of an experienced mentor and the need to constantly seek guidance from colleagues.

Given the significance of the early years of teaching, several studies have looked at the experiences and challenges of teachers in their beginning years (e.g., Farrell, 2003; Romano, 2008). However, while the issue of how prepared and confident teachers feel in their early years has received some attention in general school-based education (e.g., Fantilli \& McDougall, 2009; McIntyre, 2003; Meister \& Jenks, 2000; Romano, 2008), in teaching in diverse multilingual classrooms (Faez, 2012; Siwatu, 2007), and in the adult English as a second language (ESL) context (Faez \& Valeo, 2012), little is known about the transition of novice FSL teachers from preservice to in-service and their self-efficacy beliefs.

\section{Knowledge and Skills of an Effective L2 Teacher}

One of the greatest challenges facing teachers at the start of their careers is the need to be proficient in all knowledge and skills from the moment they enter the classroom (Kealy, 2010). However, conceptualizing teacher knowledge is not an easy task and in spite of the importance of understanding what teachers need to know in order to be effective in their roles, little information exists in both general teacher education and language teacher education. The task of conceptualizing L2 teacher knowledge is even more complex since language becomes both the subject of study and the medium of instruction. However, in spite of the complexity and because of its significance, attempts have been made to outline what constitutes L2 teacher knowledge.

Lafayette (1993) proposed that L2 teacher education must consist of three domains of knowledge: language proficiency, civilization and culture, and language analysis. J. C. Richards (1998) offered six domains for the knowledge base of language teachers, which included theories of teaching, teaching skills, communication skills and language proficiency, subject matter knowledge, pedagogical reasoning and decision making, and contextual knowledge. In their seminal article on reconceptualizing the L2 teacher knowledgebase, Freeman and Johnson (1998) acknowledged that "teachers are not empty vessels waiting to be filled with theoretical and practical knowledge" (p. 401). They emphasized the role of the teacher learner, social context, and the pedagogical process in which teachers actively try to make decisions. J. C. Richards (2010) outlined 10 aspects of teacher knowledge, including language proficiency, content knowledge, teaching skills, and contextual knowledge. Freeman (2016) noted the difference between "born expertise" (p. 43), referring to native speakers who have gained expertise because of socialization into the language, and "made over time" (p. 45), an expertise that non-native-speaking teachers have accumulated over time and learned from teacher education programs and teaching experience.

Also important to note is that there are no widely acceptable criteria for distinguishing expert teachers (Tsui, 2009). Teaching is a situated activity (Johnson, 2006, 2009) and conceptions of teacher expertise vary in different contexts and cultures (Tsui, 2003, 2009). Therefore, given the complexity of conceptualizing L2 teacher knowledge, it is not surprising that there is little agreement as to what L2 teachers need to know in order to be effective in the classroom (Freeman \& Johnson, 1998; Johnson, 2006, 2009). With the acknowledgement that teacher knowledge is context-specific, and emphasizing an understanding of the FSL context in Canada, Salvatori and MacFarlane (2009) identified 
the knowledge, skills, and experiences needed to be an effective FSL teacher in the Canadian context under four categories: general teaching methodology, L2 pedagogy, language proficiency, and cultural knowledge. The general teaching methodology category refers to the skills and knowledge that are required for effective teaching in general. The L2 teaching pedagogy category describes the knowledge and skills associated with the teaching of FSL itself. The language proficiency category relates to the knowledge and skills associated with fluency in the target language. And, finally, the cultural knowledge category refers to the understanding and appreciation of the target language culture and the benefits of linguistic duality within Canada. This study draws on Salvatori and MacFarlane's framework as the context of the study is FSL in Canada.

\section{Conceptual Framework}

Grounded in Bandura's (1977) social cognitive theory, self-efficacy is described as individuals' beliefs about their capabilities to successfully carry out a particular course of action. According to Bandura (1997), beliefs of self-efficacy are based on four sources: mastery experiences, vicarious learning, verbal persuasion, and physiological and emotional responses. Mastery experiences or performance accomplishments are built on personal achievements. If an individual believes that a performance has been successful, that information affects one's efficacy beliefs. Mastery experiences are especially important for novice teachers. Once a novice teacher has collected a variety of mastery experiences, self-efficacy beliefs become more established and once established, these beliefs are resistant to change (Bandura, 1997). The second source, vicarious learning, involves an activity modeled by someone else (Bandura, 1977). When the observer closely identifies with the model, and the model performs well, the observer's self-efficacy beliefs are heightened (Tschannen-Moran \& Woolfolk Hoy, 2007). Verbal persuasion relates to verbal interactions with others, such as encouragement or oral feedback. When individuals, such as administrators and colleagues, offer positive reinforcement regarding one's actions, one may believe that the performances have been successful (Tschannen-Moran \& Woolfolk Hoy, 2007). The fourth source, physiological responses, is the level of satisfaction one experiences in certain situations. For example, the pleasure a teacher feels from teaching an effective lesson may increase sense of efficacy, while increased heart rate or sweating attributed to the activity of teaching may lower teacher self-efficacy beliefs (TschannenMoran et al., 1998).

With regard to L2 teaching and learning, much of self-efficacy research, although scant, has involved English as a foreign language (EFL) teachers (e.g., Chacón, 2005; Eslami \& Fatahi, 2008); L2 teachers in teacher education programs (e.g., Atay, 2007; Kissau \& Algozzine, 2014); and novice ESL teachers (e.g., Faez \& Valeo, 2012). Swanson (2010, 2012, 2014) focused on L2/foreign language teaching in North America and developed a scale that he used to measure foreign language teacher efficacy to teach English, French, and Spanish. There is a paucity of studies focusing on teachers' sense of efficacy in the Canadian FSL context. Given the alarming shortage and attrition rate of novice FSL teachers across Canada, more research is clearly warranted. Teachers' selfefficacy beliefs, as discussed, are linked to student motivation and achievement (Swanson, 2014; Tschannen-Moran et al., 1998). Hence, exploring novice FSL teachers' efficacy beliefs has significant implications for teacher educators, professional development 
programs, and educational institutions committed to preparing confident and highly qualified FSL teachers.

\section{Research Questions}

The purpose of this study was to examine the self-efficacy beliefs of novice elementary FSL teachers. The questions that guided this study include the following:

1. What are the differences in the self-efficacy appraisals of novice teachers upon graduation from their teacher education programs compared to their self-efficacy appraisals at the time of study?

2. What are the differences in the self-efficacy appraisals of novice teachers in teaching core French $(\mathrm{CF})$ compared to those who teach French immersion (FI)?

\section{Methods}

The study was conducted in two phases and a mixed methods design was used. Survey data were first collected from novice CF and FI teachers in three school boards in Ontario. An online questionnaire was developed and distributed to participants in order to measure teachers' self-efficacy appraisals in areas related to delivering FSL instruction. The second phase was conducted as an exploratory follow-up to uncover factors that participants reported as contributing to their self-efficacy beliefs. Only the survey findings are reported in this article.

\section{Instruments}

The questionnaire was developed using SurveyMonkey, an online survey tool, and contained two parts: (a) Academic and Demographic section and (b) Teacher Efficacy questionnaire. The Academic and Demographic section began with two items regarding the overall self-perceived feelings of efficacy as a novice elementary FSL teacher. Using a 10point Likert scale [1 (not at all confident) to 10 (highly confident)], participants were asked to indicate how confident they felt as FSL teachers upon completion of their respective teacher education programs, as well as their self-perceived confidence at the time of the study. Each item provided the participants the opportunity to specify any factors they believed contributed to their feelings. The intention was to: (a) determine whether there was an increase or decrease in their self-efficacy appraisals from the time participants completed their teacher education programs to the time of the study, (b) identify any factors that had contributed to these feelings, (c) identify common themes, and (d) compare the CF and FI teachers' responses. This section was followed by 13 items addressing the academic and demographic backgrounds of the participants and consisted of structured items, allowing respondents to choose from provided options. This portion of the questionnaire was designed to elicit information about the participants such as their age; gender; academic background; FSL qualifications; current year of teaching; current teaching assignment (i.e., grade levels, FSL program); and dominant language.

The second section, the Teacher Efficacy questionnaire, consisted of items measuring teachers' self-efficacy in an FSL classroom. A number of documents were examined in designing this questionnaire including Tschannen-Moran and Woolfolk Hoy's 
(2001) Teacher Sense of Efficacy Scale (TSES) and Faez and Valeo's (2012) Teacher Preparedness and Efficacy Questionnaire. The TSES was designed to measure general teacher efficacy and Faez and Valeo's (2012) questionnaire was designed to measure teachers' self-perceived preparedness and efficacy to teach in adult ESL classrooms in Ontario. It was important to design the questionnaire for this study based on the knowledge and skills required for teaching in FSL classrooms in the Canadian context. Salvatori and MacFarlane's Profile and Pathways (2009) outline of pedagogical, linguistic, and cultural competencies for effective FSL teachers was drawn from to create the questionnaire items. As previously noted, Salvatori and MacFarlane outlined four areas of competency required for effective FSL instruction in Canada: general teaching methodology, L2 pedagogy, language proficiency, and cultural knowledge. All aspects relating to teachers' competency in these areas were turned into statements that allowed teachers to rate their confidence in implementing these areas of competency in the classroom. The questionnaire included a total of 24 items: eight items in general teaching methodology, eight items in L2 pedagogy, five items in language proficiency, and three items in cultural knowledge. The questionnaire is presented in the findings section.

\section{Participants}

All participants were elementary (Grades 1-8) CF or FI teachers in their first 3 years of teaching, and were part-time or full-time permanent teachers $(n=28)$. Based on the information obtained, 21 participants were female and seven were male, which is consistent with the general teaching population in Canada (Jamieson, 2007). Eight participants indicated that they were in their first year of teaching, seven participants were in their second year of teaching, 12 participants reported being in their third year of teaching, and one participant failed to indicate this information. Twenty-one participants identified English as their dominant language with one identifying equal facility with the German language. Five identified French as their dominant language, and two indicated that they were equally comfortable with both French and English. Of the 28 participants, 14 were CF teachers, and 13 taught FI. Twenty participants had completed a teacher education program in Ontario. Five indicated they had completed their teacher education outside of Canada (Australia or the United States), and three had completed their program in Quebec. Of the 28 teacher participants, only six gained FSL teacher qualifications as part of their teacher education program. Twenty-two of the 28 participants obtained FSL qualifications after completion of their teacher education program in the form of additional qualification (AQ). Important to note is that AQ courses do not typically include opportunities for practical classroom experience.

\section{Data Analysis}

The first stage of data analysis included calculating descriptive statistics (e.g., frequencies, means, and standard deviations) for self-perceived feelings of efficacy in carrying out specific tasks in each of the following four categories: general teaching methodology (eight items), L2 pedagogy (eight items), language proficiency (five items), and cultural knowledge (three items). Additionally, Cronbach's alphas were computed to determine the reliabilities of each of the four subscales and the total scale ( 24 items). The alpha coefficients of the four subscales were $0.93,0.95,0.78$, and 0.82 , respectively. The 
alpha coefficient of the total scale was 0.96 , suggesting that the scale has high reliability to measure teachers' self-perceived efficacy (Muijs, 2011). With respect to the Academic and Demographic section of the questionnaire, each participant's relevant demographic information was coded and transferred into two documents for comparison between $\mathrm{CF}$ and FI teachers, along with the perceived levels of efficacy upon completion of a teacher education program and at the time of the study.

\section{Findings}

In this section, the findings of the study are reported. First, the differences in the self-efficacy appraisals of novice teachers upon graduation from their teacher education programs and at the time of study are reported (Research Question 1). Next, the selfefficacy appraisals of CF and FI teachers in the areas of (a) general teaching methodology, (b) L2 pedagogy, (c) language proficiency, and (d) cultural knowledge are presented (Research Question 2).

\section{Self-Efficacy Appraisals of Novice Teachers}

The data related to the reported efficacy of CF and FI teachers upon completion of their teacher education programs and at the time of this study are reported in Table 1. Upon completion of their respective teacher education programs, the mean for self-perceived feelings of efficacy in delivering FSL instruction for CF teachers $(n=14)$ was $5.30(S D=$ $1.90)$, while FI teachers $(n=13)$ had a mean score of $5.00(S D=2.30)$. The data indicated that upon completion of their teacher education programs, CF and FI teachers were similar in their perceived levels of self-efficacy, with a slightly higher sense of efficacy for the CF teachers. It is noteworthy that neither CF nor FI participants perceived themselves to be fully efficacious, with both groups averaging in the middle of the scale. However, when asked to appraise their sense of efficacy at the time of the study, CF teachers had a mean score of $6.90(S D=1.40)$, and FI teachers a score of $8.10(S D=1.40)$. The data showed an average increase for CF of 1.60, from 5.30 to 6.90, while FI teachers showed an average increase of 3.10, from 5.00 to 8.10. As the data showed, FI teachers had a larger increase in their perceived sense of efficacy, almost double that of the CF teachers. Teachers of FI perceived an overall higher sense of efficacy at the time of study, averaging 2.20 above the CF teachers. 
Table 1

Self-Efficacy Appraisals of Core French (CF) and French Immersion (FI) Teachers Upon Completion of Teacher Education and at the Time of Study

\begin{tabular}{|c|c|c|c|c|c|}
\hline & $\begin{array}{l}M \text { upon } \\
\text { completion of } \\
\text { teacher } \\
\text { education } \\
\text { program }\end{array}$ & $S D$ & $\begin{array}{l}M \text { at time of } \\
\text { study }\end{array}$ & $S D$ & $\begin{array}{l}\text { Average } \\
\text { increase }\end{array}$ \\
\hline $\begin{array}{c}\text { All } \\
(n=28)\end{array}$ & 5 & 2.2 & 7.5 & 1.5 & +2.5 \\
\hline $\begin{array}{c}\mathrm{CF} \\
(n=14)\end{array}$ & 5.3 & 1.9 & 6.9 & 1.4 & +1.6 \\
\hline $\begin{array}{c}\text { FI } \\
(n=13)\end{array}$ & 5 & 2.3 & 8.1 & 1.4 & +3.1 \\
\hline $\begin{array}{c}\mathrm{CF} \text { and FI } \\
(n=1)\end{array}$ & 2 & - & 8 & - & +6 \\
\hline
\end{tabular}

\section{Self-Efficacy Appraisals of CF and FI Teachers}

General teaching methodology. Table 2 shows the data for the category of general teaching methodology. When comparing the self-efficacy beliefs of CF and FI participants in the category of general teaching methodology, analysis of the data showed a higher sense of efficacy for the FI participants, with a mean score of $7.90(S D=0.60)$, while CF participants had a mean score of $6.30(S D=0.40)$.

A particular area of high efficacy for FI teachers was classroom management $(M=$ $8.90, S D=1.00)$. This was an average of 3.90 over the CF participants' sense of efficacy in this area (see Table 2). Perceived self-efficacy in using a variety of teaching methods and reflecting on teaching was also rated high for FI teachers with a mean score of $8.40(S D=$ $0.70)$ and $8.3(S D=1.10)$, respectively. In contrast, $C F$ teachers' perceived self-efficacy was relatively low, particularly in classroom management $(M=6.00, S D=1.70)$; promoting students' critical and creative thinking $(M=5.70, S D=2.00)$; and providing effective feedback to students $(M=6.00, S D=2.20)$. 
Table 2

Self-Efficacy Appraisals of Core French (CF) and French Immersion (FI) Teachers in the Category of General Teaching Methodology

\begin{tabular}{|c|c|c|c|c|}
\hline \multirow[t]{2}{*}{ How confident are you in } & \multicolumn{2}{|c|}{$\mathrm{CF}(n=14)$} & \multicolumn{2}{|c|}{$\mathrm{FI}(n=13)$} \\
\hline & $M$ & $S D$ & $M$ & $S D$ \\
\hline Using a variety of teaching methods? & 6.5 & 1.7 & 8.4 & 0.7 \\
\hline $\begin{array}{l}\text { Differentiating your instruction to meet the } \\
\text { needs of your students? }\end{array}$ & 6.2 & 1.7 & 7.4 & 0.9 \\
\hline Managing your classroom? & 6 & 1.7 & 8.9 & 1 \\
\hline $\begin{array}{l}\text { Promoting students' critical and creative } \\
\text { thinking? }\end{array}$ & 5.7 & 2 & 7.5 & 1.3 \\
\hline $\begin{array}{l}\text { Developing assessment tools to monitor } \\
\text { students' learning? }\end{array}$ & 6.5 & 1.8 & 7.9 & 1 \\
\hline $\begin{array}{l}\text { Using the results of your assessments to monitor } \\
\text { and report on students' progress and shape } \\
\text { instruction? }\end{array}$ & 6.6 & 1.9 & 7.8 & 1 \\
\hline $\begin{array}{l}\text { Providing effective feedback to your students to } \\
\text { assist them in reflecting on their own progress? }\end{array}$ & 6 & 2.2 & 7.3 & 0.8 \\
\hline $\begin{array}{l}\text { Reflecting on your teaching in order to increase } \\
\text { its effectiveness and enhance student learning? }\end{array}$ & 6.9 & 2.3 & 8.3 & 1.1 \\
\hline Mean score & 6.3 & 0.4 & 7.9 & 0.6 \\
\hline
\end{tabular}

L2 pedagogy. Data analysis regarding L2 pedagogy, displayed in Table 3, revealed that FI participants showed a higher sense of efficacy in this category with a mean score of $7.90(S D=0.30)$, while CF teachers had a mean score of $6.30(S D=0.50)$. Overall, FI participants averaged 1.60 higher than $C F$ teachers.

The FI participants perceived themselves as being quite confident, particularly in areas such as creating a supportive and challenging learning environment $(M=8.30, S D=$ $0.90)$; planning lessons that engage students in language learning $(M=8.20, S D=1.00)$; and providing activities that support meaningful communication in French $(M=8.10, S D=$ 1.20). While $\mathrm{CF}$ teachers also perceived themselves as fairly confident in relation to creating a supportive and challenging learning environment $(M=7.20, S D=1.50)$, they scored themselves relatively low in generating and using appropriate resources $(M=5.80$, $S D=2.30)$; keeping up-to-date with current approaches to L2 learning $(M=5.80, S D=$ $2.30)$; and planning lessons that reflect theories of L2 acquisition $(M=5.90, S D=2.20)$. 
Table 3

Self-Efficacy Appraisals of Core French (CF) and French Immersion (FI) Teachers in the Category of Second Language Pedagogy

\begin{tabular}{|c|c|c|c|c|}
\hline \multirow[t]{2}{*}{ How confident are you in } & \multicolumn{2}{|c|}{$\mathrm{CF}(n=14)$} & \multicolumn{2}{|c|}{$\mathrm{FI}(n=13)$} \\
\hline & $M$ & $S D$ & $M$ & $S D$ \\
\hline $\begin{array}{l}\text { Planning lessons that engage students in } \\
\text { language learning? }\end{array}$ & 6.7 & 1.6 & 8.2 & 1 \\
\hline $\begin{array}{l}\text { Planning lessons that reflect theories of } \\
\text { second language acquisition? }\end{array}$ & 5.9 & 2.2 & 7.4 & 1.2 \\
\hline $\begin{array}{l}\text { Keeping up-to-date with and applying current } \\
\text { approaches to second language teaching? }\end{array}$ & 5.8 & 2.3 & 7.7 & 1.4 \\
\hline $\begin{array}{l}\text { Designing instructional strategies reflecting } \\
\text { currently accepted methodologies (including } \\
\text { use of technology) appropriate to your } \\
\text { instructional goals? }\end{array}$ & 6.5 & 2.4 & 8 & 0.9 \\
\hline $\begin{array}{l}\text { Selecting and adapting appropriate resources } \\
\text { to help meet the instructional and linguistic } \\
\text { needs of your students? }\end{array}$ & 6.1 & 2.3 & 7.8 & 1.1 \\
\hline $\begin{array}{l}\text { Generating and using appropriate resources to } \\
\text { help meet the instructional and linguistic } \\
\text { needs of your students? }\end{array}$ & 5.8 & 2.3 & 8 & 0.8 \\
\hline $\begin{array}{l}\text { Providing activities which support } \\
\text { meaningful communication in French? }\end{array}$ & 6.2 & 2.4 & 8.1 & 1.2 \\
\hline $\begin{array}{l}\text { Creating a supportive and challenging } \\
\text { learning environment? }\end{array}$ & 7.2 & 1.5 & 8.3 & 0.9 \\
\hline Mean score & 6.3 & 0.5 & 7.9 & 0.3 \\
\hline
\end{tabular}

Language proficiency. In the category of language proficiency, shown in Table 4, FI participants had an overall mean score of $8.50(S D=0.90)$, while CF teachers had a mean score of $6.70(S D=2.00)$. This indicated that FI teachers reported having a higher sense of efficacy in their language proficiency, averaging 1.80 above CF teachers.

One area of high self-efficacy for CF teachers was in knowing how the French language works, averaging a score of $8.30(S D=1.80)$. However, this score was still lower than that of their FI colleagues, who averaged $9.20(S D=0.90)$ in this area. Another area of particular interest is in relation to the amount of time spent using French in the classroom. Teachers of CF averaged $6.30(S D=2.50)$, which is relatively lower than FI teachers, who had a mean score of $8.90(S D=1.00)$. Reaching out to the French community was an area of relatively low reported efficacy for both CF and FI teachers, with a mean score of 3.50 $(S D=2.60)$ and $6.90(S D=2.10)$, respectively. 
Table 4

Self-Efficacy Appraisals of Core French (CF) and French Immersion (FI) Teachers in the Category of Language Proficiency

\begin{tabular}{|c|c|c|c|c|}
\hline \multirow[t]{2}{*}{ How confident are you in } & \multicolumn{2}{|c|}{$\mathrm{CF}(n=14)$} & \multicolumn{2}{|c|}{ FI $(n=13)$} \\
\hline & $M$ & $S D$ & $M$ & $S D$ \\
\hline $\begin{array}{l}\text { Using French in the classroom most } \\
\text { or all of the time? }\end{array}$ & 6.3 & 2.5 & 8.9 & 1 \\
\hline $\begin{array}{l}\text { Providing a linguistic model for } \\
\text { students? }\end{array}$ & 7.7 & 1.9 & 8.9 & 1 \\
\hline $\begin{array}{l}\text { Knowing how the French language } \\
\text { works (i.e., grammar, pronunciation, } \\
\text { etc.)? }\end{array}$ & 8.3 & 1.8 & 9.2 & 0.9 \\
\hline $\begin{array}{l}\text { Setting attainable and worthwhile } \\
\text { learning goals for your students? }\end{array}$ & 7.9 & 1.4 & 8.8 & 0.7 \\
\hline $\begin{array}{l}\text { Reaching out to the French } \\
\text { community to enhance your } \\
\text { instruction? }\end{array}$ & 3.5 & 2.6 & 6.9 & 2.1 \\
\hline Mean score & 6.7 & 2 & 8.5 & 0.9 \\
\hline
\end{tabular}

Cultural knowledge. The data in Table 5 indicate that, with regard to a sense of efficacy in cultural knowledge, FI participants reported a higher sense of efficacy over CF participants, with mean scores of $8.60(S D=0.40)$ and $7.10(S D=0.90)$, respectively. Teachers of FI reported a higher sense of cultural knowledge, averaging 1.5 above CF teachers.

While both FI and CF participants reported a higher sense of efficacy in promoting the value of learning French, as shown with mean scores of $8.90(S D=1.00)$ and 8.00 $(S D=1.90)$, respectively, the most notable difference appeared in the participants' sense of efficacy in understanding French culture and language and how to link them with one another. The FI participants perceived themselves as highly efficacious in this area with a mean score of $8.70(S D=1.5)$, while $C F$ teachers had a mean score of $6.20(S D=2.5)$. 
Table 5

Self-Efficacy Appraisals of Core French (CF) and French Immersion (FI) Teachers in the Category of Cultural Knowledge

\begin{tabular}{|c|c|c|c|c|}
\hline \multirow[t]{2}{*}{ How confident are you in } & \multicolumn{2}{|c|}{$\mathrm{CF}(n=14)$} & \multicolumn{2}{|c|}{$\mathrm{FI}(n=13)$} \\
\hline & $M$ & $S D$ & $M$ & $S D$ \\
\hline $\begin{array}{l}\text { Understanding the French culture } \\
\text { and language and how to link them } \\
\text { with one another? }\end{array}$ & 6.2 & 2.5 & 8.7 & 1.5 \\
\hline $\begin{array}{l}\text { Promoting the value of learning } \\
\text { French? }\end{array}$ & 8 & 1.9 & 8.9 & 1 \\
\hline $\begin{array}{l}\text { Welcoming diverse learners and } \\
\text { valuing the benefits of intercultural } \\
\text { awareness and understanding within } \\
\text { the language program? }\end{array}$ & 7.2 & 1.7 & 8.2 & 1.3 \\
\hline Mean score & 7.1 & 0.9 & 8.6 & 0.4 \\
\hline
\end{tabular}

\section{Discussion}

\section{Self-Efficacy Appraisals of Novice Teachers}

Overall, the FSL teachers in this study did not feel particularly confident to teach in FSL classrooms upon completion of their teacher education programs. Their mean selfappraisals were in the middle of the scale (5 out of 10). Inadequate teacher training has been well documented as an area of concern for beginning teachers (Fantilli \& McDougall, 2009; McIntyre, 2003). Further to that, as outlined in Bandura's (1977) self-efficacy theory, vicarious experiences are an important source of information regarding one's level of selfefficacy. Since many participants had little or no FSL classroom practice teaching upon completion of their respective teacher education programs, they had not been provided with opportunities to observe the performances of more experienced FSL teachers. Another explanation of the findings in this study could be that 22 of the 28 teacher participants did not complete their FSL qualifications until after the completion of the teacher education program, and additional qualifications (AQ) courses typically do not contain opportunities for practical classroom experience. The fact that many participants had little or no FSL classroom practice teaching as part of their teacher education program meant that they had not been provided with opportunities to observe the performances of more experienced FSL teachers.

However, despite initially feeling relatively inefficacious $(M=5)$, with experience, most participants expressed an increase in their overall feelings of efficacy, from the time they completed their teacher education program to the time of the study, with an increase of the overall mean to 7.5. As Bandura (1997) pointed out, it is during these early years that efficacy beliefs are most pliable. Given that the majority of participants expressed an increase in efficacy beliefs, it is possible that they had begun collecting a variety of mastery experiences and had come to realize that their performances in the classroom had been successful. In a study conducted in the Canadian ESL context, Faez and Valeo (2012) 
reported that practicing teachers found practicum to be one of the most useful aspects of their teacher education program. Therefore, teacher education programs should consider the inadequacy of the preparation of FSL teachers (via AQ courses) with regard to the practice teaching element in qualifying teachers.

\section{Core French Versus French Immersion Teachers}

When comparing CF teachers with their FI colleagues, neither group felt particularly confident in their roles upon completion of their teacher education programs, with both groups averaging mid-scale. However, at the time of the study, the increase in the overall feelings of efficacy of the FI teachers, as indicated by their scores, was almost double those of the CF teachers. The mean increase for FI teachers was 3.1 compared to an average increase of 1.6 for CF teachers.

Two important factors in making self-efficacy appraisals are an analysis of the teaching task and its context, and an assessment of one's capability to perform the task successfully (Knoblauch \& Woolfolk Hoy, 2008). These appraisals are made after an evaluation of the requirements of the activity, of the level of difficulty, and of what it would take to succeed. E. Richards (2002) reported that two issues facing CF teachers were in relation to the short amount of time allotted for $\mathrm{CF}$ instruction in the school day and lack of available classroom space. Given the amount of time that CF teachers have with their students, considering transition times, transporting materials, and entry and exit routines, it is not surprising that many CF teachers may feel unsuccessful in delivering an effective FSL program. Furthermore, not having their own classrooms may give the impression to colleagues, parents, and students that CF is not as important a subject as others and that the program does not warrant attention.

Further to that, FI teachers averaged higher than CF teachers in all items of the Teacher Efficacy Questionnaire. This is not surprising given past research (e.g., E. Richards, 2002) with regard to the status and marginalization of CF in the school system. Most often CF teachers do not have their own classroom (Lapkin et al., 2006; Mollica et al., 2005). They are sometimes the only FSL teacher in the school, where they have little opportunity for collaboration with more experienced colleagues and no chance of having a qualified mentor at the school or resources that are critical for the development of novice teachers (Farrell, 2003; Fantilli \& McDougall, 2009; McIntyre, 2003; Romano, 2008). Regarding mastery experiences (Bandura, 1997), perhaps CF teachers are not receiving any specific constructive feedback as they do not have much opportunity to work with other teachers and learn through collaboration. This is not necessarily the case for FI teachers, who would have more opportunities for collaboration and a higher likelihood of having a mentor, given that there would be other FI teachers at the school.

An important element identified in this study was with regard to the French language proficiency of the participants. The average self-perceived proficiency of FI teachers was higher than that of CF teachers (8.5 compared to 6.7). Choi and Lee (2016) reported positive associations and interdependence between self-efficacy and language proficiency. Teachers may question whether they are capable of performing the teaching tasks within particular contexts, and may consider factors such as the availability of resources, students' abilities and motivation, and teacher strategies (Knoblauch \& Woolfolk Hoy, 2008). In the case of FSL teachers, they may ask themselves whether they possess the language proficiency to perform well as an efficacious L2 teacher. Therefore, given the 
higher ratings of their French proficiency, it is not surprising that FI teachers perceived themselves to be more efficacious in their pedagogical skills. Teachers of FI in this study also self-reported a higher level of cultural knowledge, which may also have contributed to their higher self-perceived efficacy in delivering FSL instruction.

\section{Implications, Limitations, and Conclusions}

This study has revealed that, in general, novice FSL teachers in elementary schools in Ontario are not feeling particularly confident upon completion of their teacher education programs. Inadequate FSL training during teacher education programs or a lack of practicum placements in an FSL classroom are important considerations in preparing FSL teachers. It was not clear whether the lack of adequate preparation of participants was the result of their program choice or the program's inability to provide placements. However, teachers' inadequate sense of preparation after completion of their teacher education does suggest that those wishing to teach FSL must be provided with more opportunities during their teacher education programs for practical experience in FSL classrooms, as experience was an important factor connected to the increased sense of efficacy from the completion of a teacher education program to the time of the study.

Language proficiency was also identified as an area of concern. Teacher education programs and school boards should continue to provide professional development opportunities for teachers to enhance their French language skills; however, it is also essential that teachers take advantage of the opportunities offered as well as any additional resources on their own time to improve their French language proficiency. School boards should also consider teacher collaboration as an important element in teachers' professional development. Collaboration with other teachers can provide a chance for FSL teachers to practice speaking French and improve their teaching skills.

Also, with regard to the status of CF, administrators must be aware of the amount of support given to new teachers and the way that the CF program is viewed in their schools. Showing support for the program (i.e., distribution of resources, assignment of classrooms, release time for collaboration with a mentor and/or colleagues) will send a message to all stakeholders that the CF program and its teachers are valuable members of the school community.

There were several limitations that should be considered when analyzing the results of this study. One limitation was the sample size. This study involved a relatively small number of participants (i.e., 27 novice teachers) who responded to the questionnaire. This study was also limited to three school boards in the context of Ontario, and the majority of participants who responded to the questionnaire were from one school board in particular. Another limitation was the fact that participants were asked at the time of the study to appraise their efficacy beliefs upon completion of their teacher education program. These perceptions may not have been accurate, given the amount of time that had passed, particularly for those who were in their third year of teaching. A final limitation was related to the questionnaire. This questionnaire has not been validated and the psychometric properties were not measured. Despite these limitations, this study does provide useful insight into many of the issues facing novice elementary FSL teachers in Ontario.

It is hoped that this study will encourage teacher education programs to review the content of their programs and how FSL teachers are prepared. Similarly, school boards and 
administrators are encouraged to re-examine the position and support given to FSL programs, particularly the $\mathrm{CF}$ program, within their establishments, to ensure that beginning FSL teachers are entering their new careers feeling confident, well prepared, and supported.

Correspondence should be addressed to Farahnaz Faez.

Email: ffaez@uwo.ca

\section{Acknowledgment}

This paper is based on the first author's master's thesis.

\section{References}

Atay, D. (2007). Beginning teacher efficacy and the practicum in an EFL context. Teacher development, 11(2), 203-219.

Bandura, A. (1977). Self-efficacy: Toward a unifying theory of behavioural change. Psychological Review, 84, 191-215.

Bandura, A. (1997). Self-efficacy: The exercise of control. New York, NY: W.H. Freeman.

Chacón, C. T. (2005). Teachers' perceived efficacy among English as a foreign language teachers in middle schools in Venezuela. Teaching and Teacher Education, 21, 257272.

Choi, E., \& Lee, J. (2016). Investigating the relationship of target language proficiency and self-efficacy among nonnative EFL teachers. System, 58, 49-63.

Eslami, Z. R., \& Fatahi, A. (2008). Teachers' sense of self-efficacy, English proficiency, and instructional strategies: A study of non-native EFL teachers in Iran. TESL-EJ, 11(4), 1-19.

Faez, F. (2012). Diverse teachers for diverse students: Internationally educated and Canadian-born teachers' preparedness to teach English language learners. Canadian Journal of Education, 35(3), 64-84.

Faez, F., \& Valeo, A. (2012). TESOL teacher education: Novice teachers' perceptions of their preparedness and efficacy in the classroom. TESOL Quarterly, 46(3), 450-471.

Fantilli, R. D., \& McDougall, D. E. (2009). A study of novice teachers: Challenges and supports in the first years. Teaching and Teacher Education, 25(6), 814-825.

Farrell, T. S. C. (2003). Learning to teach English language during the first year: Personal influences and challenges. Teaching and Teacher Education, 19(1), 95-111.

Freeman, D. (2016). Educating second language teachers: The same things done differently. Oxford, United Kingdom: Oxford University Press.

Freeman, D., \& Johnson, K. E. (1998). Reconceptualizing the knowledge base of language teacher education. TESOL Quarterly, 32(3), 397-417.

Gibson, S., \& Dembo, M. H. (1984) 'Teacher efficacy: A construct validation.' Journal of Educational Psychology, 76, 569-582.

Government of Canada. (2003). The next act: New momentum for Canada's linguistic duality/The action plan for official languages. Retrieved from http://www.cpfnb.com/articles/ActionPlan_e.pdf 
Government of Canada. (2008). Roadmap for Canada's linguistic duality 2008-2013: Acting for the future. Retrieved from http://www.pch.gc.ca/pgm/slo-ols/strateng.cfm

Government of Canada. (2013). Roadmap for Canada's official languages 2013-2018: Education, immigration, communities. Retrieved from http://www.pch.gc.ca/eng/1358263602229/1358263791285

Henson, R. K. (2001). A reliability generalization study of the teacher efficacy scale and related instruments. Educational and Psychological Measurement, 61(3), 404-420.

Jamieson, B. (2007, June). Male presence in teaching continues to decline. Professionally Speaking. Retrieved from http://professionallyspeaking.oct.ca/june_2007/male_teachers.asp

Johnson, K. E. (2006). The sociocultural turn and its challenges for second language teacher education. TESOL Quarterly, 40(1), 235-257.

Johnson, K. E. (2009). Second language teacher education: A sociocultural perspective. New York, NY: Routledge.

Kealy, M. V. (2010). A leadership focus on teacher effectiveness: Support for novice teachers. Journal of Special Education Leadership, 23(1), 52-54.

Kissau, S., \& Algozzine, B. (2014). The impact of mode of instructional delivery on second language teacher self-efficacy. ReCALL, 27(2), 239-256.

Knoblauch, D., \& Woolfolk Hoy, A. (2008). "Maybe I can teach those kids." The influence of contextual factors on student teachers' efficacy beliefs. Teaching and Teacher Education, 24, 166-179.

Lafayette, R. C. (1993). Subject-matter content: What every foreign language teacher needs to know. In G. Guntermann (Ed.), Developing language teachers for a changing world (pp. 125-157). Lincolnwood, IL: National Textbook.

Lapkin, S., MacFarlane, A., \& Vandergrift, L. (2006). Teaching French in Canada: FSL teachers' perspectives. Ottawa, ON: Canadian Teachers' Federation.

Lapkin, S., Mady, C., \& Arnott, S. (2009). Research perspectives on core French: A literature review. Canadian Journal of Applied Linguistics, 12(2), 6-30.

McIntyre, F. (2003). Transition to teaching: New teachers of 2001 and 2002. Report of their first two years of teaching in Ontario. Toronto, ON: Ontario College of Teachers.

Meister, D., \& Jenks, C. (2000). Making the transition from preservice to inservice teaching: Beginning teachers' reflections. Action in Teacher Education, 22(3), 1-11.

Mollica, A., Philips, G., \& Smith, M. (2005). Teaching and learning French as a second language: Core French in the elementary schools in Ontario. Report prepared for the Ontario Modern Language Teachers' Association.

Muijs, D. (2011). Doing quantitative research in education with SPSS (2 ${ }^{\text {nd }}$ ed.). Thousand Oaks, CA: Sage.

Richards, E. (2002). Positioning the elementary core French teacher: An investigation of workplace marginality (Unpublished doctoral dissertation). Retrieved from ProQuest, UMI Dissertations. (NQ69245).

Richards, J. C. (1998). Beyond training: Perspectives on language teacher education. Cambridge University Press.

Richards, J. C. (2010). Competence and performance in language teaching. RELC Journal, 41(2), 101-122. doi:10.1177/0033688210372953 
Romano, M. (2008). Successes and struggles of the beginning teacher: Widening the sample. The Educational Forum, 72, 63-78.

Ross, J. A. (1998). The antecedents and consequences of teacher efficacy. In J. Brophy (Ed.), Advances in research on teaching: Expectations in the classroom (pp. 49-73). Greenwich, CT: JAI Press.

Salvatori, M. (2009). A Canadian perspective on language teacher education: Challenges and opportunities. The Modern Language Journal, 93, 287-291.

Salvatori, M., \& MacFarlane, A. (2009). Profile and pathways: Supports for developing FSL teachers' pedagogical, linguistic, and cultural competencies. Canadian Association of Second Language Teachers. Retrieved from http://www.caslt.org/pdf/en/what-we-do/caslt-panorama-profilepathways-e.pdf

Siwatu, K. O. (2007). Preservice teachers' culturally responsive teaching self-efficacy and outcome expectancy beliefs. Teaching and Teacher Education, 23, 1086-1101.

Standing Committee on Official Languages. (2014). The state of French second-language programs in Canada. Ottawa, ON: Canada

Statistics Canada. (2011). Linguistic characteristics of Canadians. (Language, 2011 Census of Population.) Retrieved from http://www12.statcan.gc.ca/censusrecensement/2011/as-sa/98-314-x/98-314-x2011001-eng.pdf

Swanson, P. (2010). Teacher efficacy and attrition: Helping students at introductory levels of language instruction appears critical. Hispania, 93(2), 305-321.

Swanson, P. (2012). Second/Foreign language teacher efficacy and its relationship to professional attrition. Canadian Modern Language Review, 68(1), 78-101.

Swanson, P. (2014). The power of belief: Spanish teachers' sense of efficacy and student performance on the national Spanish exams. Hispania, 97(1), 5-20.

Tait, M. (2008). Resilience as a contributor to novice teacher success, commitment, and retention. Teacher Education Quarterly, 35(4), 57-75.

Tschannen-Moran, M., \& Woolfolk Hoy, A. (2001). Teacher efficacy: capturing an elusive construct. Teaching and Teacher Education, 17, 783-8.

Tschannen-Moran, M., \& Woolfolk Hoy, A. (2007). The differential antecedents of selfefficacy beliefs of novice and experienced teachers. Teaching and Teacher Education, 23, 944-956.

Tschannen-Moran, M., Woolfolk Hoy, A., \& Hoy, W. (1998). Teacher efficacy: Its meaning and measure. Review of Educational Research, 68(2), 202-248.

Tsui, A. B. M. (2003). Understanding expertise in teaching: Case studies of second language teachers. New York, NY: Cambridge University Press.

Tsui, A. B. M. (2009). Teaching expertise: Approaches, perspectives, and characterizations. In. A. Burns \& J. C. Richards (Eds.), The Cambridge guide to second language teacher education (pp. 190-198). New York, NY: Cambridge University Press.

Woolfolk Hoy, A. (2000, April). Changes in teacher efficacy during the early years of teaching. Paper presented at the annual meeting of the American Educational Research Association, New Orleans, LA. 